patients with few comorbidities will tolerate aortic repair more so than will older patients who are obese and otherwise health compromised, and thus, a complex aortic repair can be "offset" when performed in young healthy patients.

This study substantiates that complex operations can be performed via less-invasive incisions with excellent results. However, when dealing with an acute type A aortic dissection, most surgeons in a dedicated, high-volume aortic center will follow the principle of Occam's razor, keeping the operation as simple and safe as possible. Central to our understanding of the treatment for acute type A aortic dissection is that unless specific circumstances dictate the immediate inclusion of transverse aortic arch-namely, the presence of a heritable thoracic aortic disease, a fusiform aneurysm of the arch itself, or frank destruction of the arch by the dissection process-any such repair is prophylactic in nature. At the end of the day, the surgeon's goal is to enhance immediate survival of a life-threatening acute aortic event.

\section{References}

1. Evangelista A, Isselbacher EM, Bossone E, Gleason TG, Eusanio MD, Sechtem U, et al. Insights from the International Registry of Acute Aortic Dissection: a 20-year experience of collaborative clinical research. Circulation. 2018;137:1846-60.

2. Poon SS, Theologou T, Harrington D, Kuduvalli M, Oo A, Field M. Hemiarch versus total aortic arch replacement in acute type A dissection: a systematic review and meta-analysis. Ann Cardiothorac Surg. 2016;5:156-73.

3. Xie XB, Dai XF, Fang GH, Qiu ZH, Jiang DB, Chen LW. Extensive repair of acute type A aortic dissection through a partial upper sternotomy and using complete stent-graft replacement of the arch. J Thorac Cardiovasc Surg. 2022;164:1045-52.

4. Chen LW, Dai XF, Zhang GC, Lu L. Total aortic arch reconstruction with open placement of triple-branched stent graft for acute type A dissection. J Thorac Cardiovasc Surg. 2010;139:1654-5.e1.

5. Jiang H, Liu Y, Yang Z, Ge Y, Li L, Wang H. Total arch replacement via single upper-hemisternotomy approach in patients with type A dissection. Ann Thorac Surg. 2020;109:1394-9.

6. Zhu JM, Qi RD, Liu YM, Zheng J, Xing XY, Sun LZ. Repair of type A dissection with mitral regurgitation using total arch replacement with mitral valve surgery. $J$ Card Surg. 2015;30:438-41

\title{
Commentary: "Incidental" total aortic stent graft in acute type $A$ dissection surgery
}

\author{
John A. Elefteriades, MD, PhD (hon), and \\ Bulat A. Ziganshin, MD, PhD
}

How much to do at the time of acute aortic dissection has long been a topic of debate among cardiothoracic surgeons. We have felt that doing an ascending resection with hemiarch and then delivering the patient to intensive care unit alive, awake, and not bleeding represents an outcome of which the surgeon can be proud. ${ }^{1}$ A life has been saved.

From the Aortic Institute at Yale-New Haven Hospital, Yale University School of Medicine, New Haven, Conn.

Disclosures: Dr Elefteriades reported principal, CoolSpine; consultant for CryoLife; and data/safety monitoring board for Terumo. Dr Ziganshin reported no conflicts of interest.

The Journal policy requires editors and reviewers to disclose conflicts of interest and to decline handling or reviewing manuscripts for which they may have a conflict of interest. The editors and reviewers of this article have no conflicts of interest

Received for publication Oct 30, 2020; revisions received Oct 30, 2020; accepted for publication Oct 30, 2020; available ahead of print Nov 9, 2020.

Address for reprints: John A. Elefteriades, MD, PhD (hon), Aortic Institute at Yale New Haven, 789 Howard Ave, Clinic Building CB317, New Haven, CT 06510 (E-mail: john.elefteriades@yale.edu).

J Thorac Cardiovasc Surg 2022;164:1054-6

$0022-5223 / \$ 36.00$

Copyright (c) 2020 by The American Association for Thoracic Surgery

http://dx.doi.org/10.1016/j.jtcvs.2020.10.118

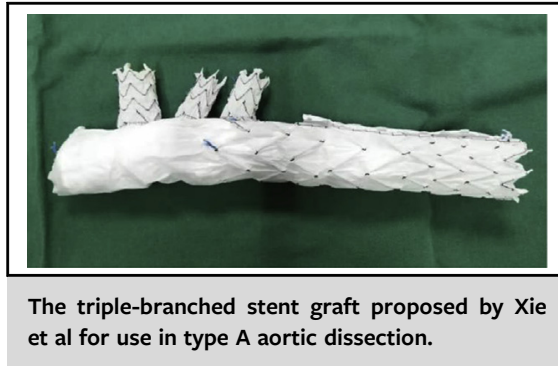

CENTRAL MESSAGE

The authors have presented an imaginative method to incorporate a simply delivered stent graft into the hemi-arch operation for acute type A aortic dissection.

Doing more, in expert hands, may be indicated to improve the long-term prognosis down the road.

We read with interest the article by Xie and colleagues ${ }^{2}$ describing their experience with "extensive repair of acute type A aortic dissection through a partial upper sternotomy and using complete stent-graft replacement of the arch." We congratulate the authors on their novel technique. They are to be congratulated for their creativity and courage. 
The readers should note that the novel arch graft comes with 3 pre-attached stent side-arm grafts that are simply slid into each of the 3 head vessels.

The report really has 2 different components, which we will discuss separately.

\section{COMPLETE AORTIC ARCH STENT GRAFT}

This idea is quite attractive, even to this commenter, who generally prefers traditional open, sewn anastomoses. The attractive feature is specifically that, for little effort beyond a traditional hemi-arch replacement, one may well gain some branch vessel and downstream descending aortic remodeling and protection. The novel endograft is simply inserted through a traditional hemi-arch resection. The main graft fits into the descending aorta and the branches all fit automatically into the arch vessels (innominate, left carotid, and left subclavian). The time required seems minimal. The convenience level seems high. After installation of the branched endograft, one does the hemi-arch anastomosis in the standard fashion, incorporating both the dissected aortic wall and the proximal end of the endograft. Whatever branch vessel and descending aortic remodeling and protection may be afforded by the endograft are accrued essentially "free," with little apparent extra effort or inconvenience.

\section{PARTIAL STERNOTOMY}

This component is not so novel, as there is wide experience in performing all sorts of open-heart surgery, including aortic, through more limited incisions than a sternotomy. That having been said, the authors' incision looks quite generous. One would not know immediately from their video that this was a partial sternotomy. The opening certainly extends down to within a couple centimeters of the lower skin towel in the epigastrium. The skin incision is not included in the video to give us a better appreciation of the extent of the skin incision. The authors explain (in the Discussion) that in their "method" they do extend their incision to the fifth or sixth intercostal space when necessary, which is essentially to the bottom of the sternum. However, considerations regarding the incision should not interfere with appreciation of the convenient stent graft component of the authors' method.

Additional observations are as follows:

\section{LONG-TERM FOLLOW-UP}

The authors provide no follow-up beyond the initial hospitalization in this report. One wonders, in viewing the video, whether the stent grafts inserted easily into the arch branches and the descending aorta will ever produce a seal or achieve control of the arch sac that is created. The way the operation is configured, as long as the hemiarch anastomosis to the novel graft is hemostatic, any "endoleak" from the aortic arch vessels will be contained

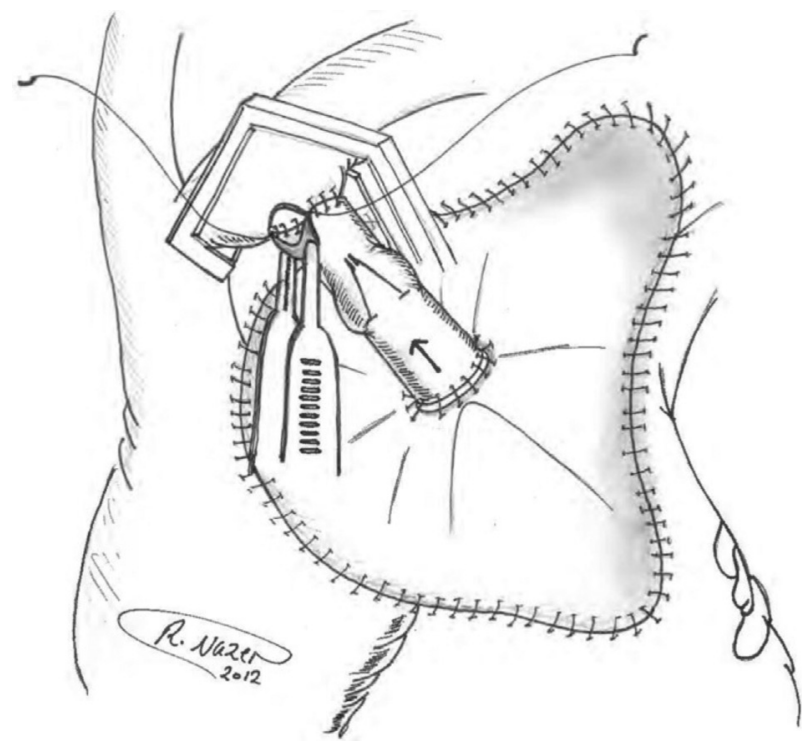

FIGURE 1. The pericardial patch of the Cabrol fistula has been sewn in place over the aortic operative field (borders: connective tissue on right side of main pulmonary artery, right ventricular outflow tract connective tissues, superior vena cava, connective tissues on lower edge of innominate vein). The inflow end of a biologic venous graft (bovine jugular vein or human saphenous or iliac vein) has been anastomosed to the top, center of the pericardial patch. The outflow end of the venous graft is being anastomosed to the innominate vein under side-biting control (reproduced with permission from Elefteriades and colleagues ${ }^{3}$ ).

within the neo-aorta. The endograft construct may just be found "swimming" within the natural confines of the aortic wall. Computed tomography scanning would be required for evaluation of such massive "endoleak." Cardiothoracic surgeons would look forward to mid-term and long-term follow-up reports from this group. Anatomic benefits in follow-up need to be demonstrated to justify the technique.

More minor observations include the following:

\section{Triple Arterial Cannulation}

The femoral artery and the right axillary artery were cannulated. Later, the left common carotid artery was cannulated directly in the field. This triple arterial cannulation seems to add unnecessary complexity for unclear reasons.

\section{Inclusion Criteria}

The inclusion criteria for the study of this novel technique are quite confusing. Age for inclusion is younger than 55 years, except when certain morphologic dissection criteria apply, in which case patients older than 55 years are included.

\section{Cabrol Fistula}

We also have found the Cabrol a useful technique, applying it very rarely-about once or twice a year. We described a technique for "valving" the fistula, so that 
flow only goes in the desired direction. ${ }^{3,4}$ (See Figure 1.) Otherwise, the venous backflow can make one regret ever having constructed the fistula (especially If venous pressure is high). The authors imply frequent use of the Cabrol fistula to control bleeding in their endograft series. They have developed their own technique for closing the transverse cardiac sinus to optimize benefit from the Cabrol fistula (preventing blood from escaping from the Cabrol fistula and draining into the pericardium). ${ }^{5}$ Widespread application of the Cabrol fistula is not necessarily bad, but one wonders what shortcomings may be hidden in potential chronic, persistent Cabrol internal "drainage" (with left-to-right shunting).

The authors have created an imaginative stent. Medianterm follow-up will show if the head vessel stents can rival a sutured anastomosis. Clinical and radiologic surveillance will determine if the novel stent graft controls the dissection process.

Congratulations to the authors on their creativity and their excellent clinical results.

\section{References}

1. Elefteriades JA. What operation for acute type A dissection? J Thorac Cardiovasc Surg. 2002;123:201-3.

2. Xie X-B, Dai X-F, Fang G-H, Qiu Z-H, Jiang D-B, Chen L-W. Extensive repair of acute type A aortic dissection through a partial upper sternotomy and using complete stent-graft replacement of the arch. J Thorac Cardiovasc Surg. 2022;164: $1045-52$.

3. Elefteriades JA, Youssef S, Rousou L, Nazer R. Novel valved graft modification of Cabrol fistula for bleeding after aortic root surgery. Ann Thorac Surg. 2012;94: 1741-3.

4. Elefteriades JA. Mechanism to valve a Cabrol fistula for bleeding control. Aorta (Stamford). 2013;1:65-6.

5. Chen LW, Wu XJ, Dai XF. Transverse pericardial sinus closure in acute type A aortic dissection operation. Ann Thorac Surg. 2017;104:e351-3.
See Article page 1045

\section{Commentary: Is the type of chest opening the main problem in surgery for acute type $A$ aortic dissection?}

\author{
Jean Bachet, MD, FEBCTS
}

In their article in this issue of the Journal, Xie and coworkers ${ }^{1}$ report on a particularly rare and surprising experience of surgical repair of acute type A aortic dissection. Their report raises several important questions.

The authors describe procedures in which type A dissections were systematically repaired using a 3-branched stent-

\footnotetext{
From the Association Pour le Developpement et l'Amelioration des Techniques de Depistage et de Traitement des Maladies Cardiovasculaires (ADETEC), Suresnes, France.

Disclosures: The author reported no conflicts of interest.

The Journal policy requires editors and reviewers to disclose conflicts of interest and to decline handling or reviewing manuscripts for which they may have a conflict of interest. The editors and reviewers of this article have no conflicts of interest.

Received for publication Nov 4, 2020; revisions received Nov 4, 2020; accepted for publication Nov 5, 2020; available ahead of print Nov 19, 2020.

Address for reprints: Jean Bachet, MD, FEBCTS, ADETEC, 1 Place Marcel Legras, 92150 Suresnes, France (E-mail: jean.bachet@yahoo.fr).

J Thorac Cardiovasc Surg 2022;164:1056-7

$0022-5223 / \$ 36.00$

Copyright (c) 2020 by The American Association for Thoracic Surgery

http://dx.doi.org/10.1016/j.jtcvs.2020.11.019
}

Check for updates

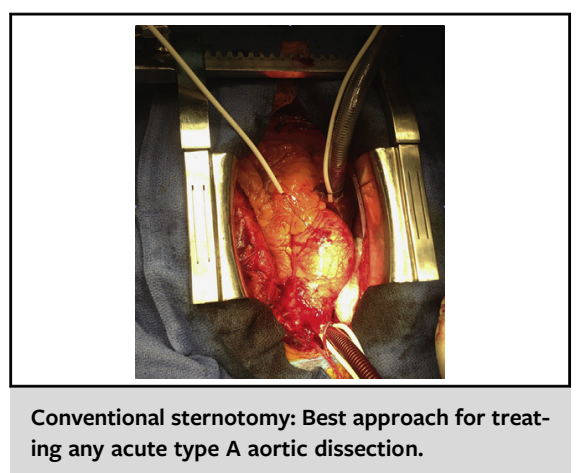

CENTRAL MESSAGE

In surgery for acute type A dissection, the safest possible techniques should be used to address both expected and unexpected difficulties. Can this be achieved through limited approaches?

graft placed in the proximal descending aorta, the aortic arch, and the supra-aortic vessels and associated with a conventional prosthetic replacement of the ascending aorta with or without root repair. This is the first surprise. Indeed, even though trifurcated prosthetic grafts associated with a 